

\title{
Evaluation of the Factors Contributing to Levonorgestrel Binding in Addition Cure Silicone Elastomer Vaginal Rings
}

Malcolm, K., Murphy, D., McCoy, C., Boyd, P., Kumar, S., Fetherston, S., Brimer, A., Holt, J., Blanda, W., Devlin, B., Nuttall, J., Gilmour, C., \& Derrick, T. (2014). Evaluation of the Factors Contributing to Levonorgestrel Binding in Addition Cure Silicone Elastomer Vaginal Rings. Poster session presented at HIV R4P - HIV Research for Prevention, Cape Town, South Africa. http://hivr4p.org/program/posters/posters-theme

Queen's University Belfast - Research Portal:

Link to publication record in Queen's University Belfast Research Portal

Publisher rights

Copyright 2014 The Authors

\section{General rights}

Copyright for the publications made accessible via the Queen's University Belfast Research Portal is retained by the author(s) and / or other copyright owners and it is a condition of accessing these publications that users recognise and abide by the legal requirements associated with these rights.

Take down policy

The Research Portal is Queen's institutional repository that provides access to Queen's research output. Every effort has been made to ensure that content in the Research Portal does not infringe any person's rights, or applicable UK laws. If you discover content in the Research Portal that you believe breaches copyright or violates any law, please contact openaccess@qub.ac.uk. 


\section{EVALUATION OF THE FACTORS CONTRIBUTING TO LEVONORGESTREL BINDING IN ADDITION CURE SILICONE ELASTOMER VAGINAL RINGS}

Karl Malcolm 1 , Diarmaid Murphy ${ }^{1}$, Clare McCoy ${ }^{1}$, Peter Boyd ${ }^{1}$, Sandeep Kumar ${ }^{1}$, Susan Fetherston ${ }^{1}$, Andrew Brimer ${ }^{2}$, Jonathon Holt ${ }^{2}$, Wendy Blanda ${ }^{2}$, Brid Devlin ${ }^{2}$, Jeremy Nuttall ${ }^{2}$, Chris Gilmour ${ }^{2}$, Tiffany Derrick ${ }^{2}$

'Queen's University Belfast, UK, ${ }^{2}$ International Partnership for Microbicides (IPM), USA.

With the dapivirine (DPV)-releasing silicone elastomer (SE) vaginal ring (VR) now in Phase III clinical studies, there is now considerable interest in developing next-generation rings that could additionally provide contraception. Levonorgestrel (LNG Fig. 1) is a second generation synthetic progestin used as an active ingredient in various hormonal contraceptives, including oral pills, intrauterine devices, and contraceptive implants. It is also the lead progestin candidate for use in future multipurpose prevention technology (MPT) products. Despite having previously been incorporated into SE devices, LNG's propensity to react

$\begin{aligned} & \text { with addition cure SE } \\ & \text { systems has scarcely } \\ & \text { been reported. Here, } \\ & \text { we investigate this } \\ & \text { phenomenon and offer } \\ & \text { some solutions. }\end{aligned}$

Figure 1. Chemical structure of $L N G$. The ethinyl group (top right) and

the enone group (bottom left) have the potential to react with addition cure silicone elastomers.

SEs are available with different cure chemistries. Addition-cure SEs involve the platinum-catalysed reaction between two types of silicone polymer - one containing silane groups ( $\mathrm{Si}-\mathrm{H})$ and the other containing vinylsilane groups ( $\mathrm{Si}-\mathrm{C}=\mathrm{C}$ ) (Fig. 2). These systems are preferred for medical and drug delivery applications, since they do not produce reaction by-products. However, certain substances are known to inhibit the addition-cure reaction.

A problem with LNG-loaded SE VRs was first noted with combination DPV (200mg) + LNG (32mg) matrix-type rings manufactured $\left(160^{\circ} \mathrm{C}, 90 \mathrm{~s}\right.$ cure time) using micronised LNG and MED-4870, a high-temperature addition-cure SE supplied by Nusil. Specifically, the rings showed zero in vitro release of the LNG component. Furthermore, attempts to solvent-extract LNG from the rings immediately after manufacture revealed that no

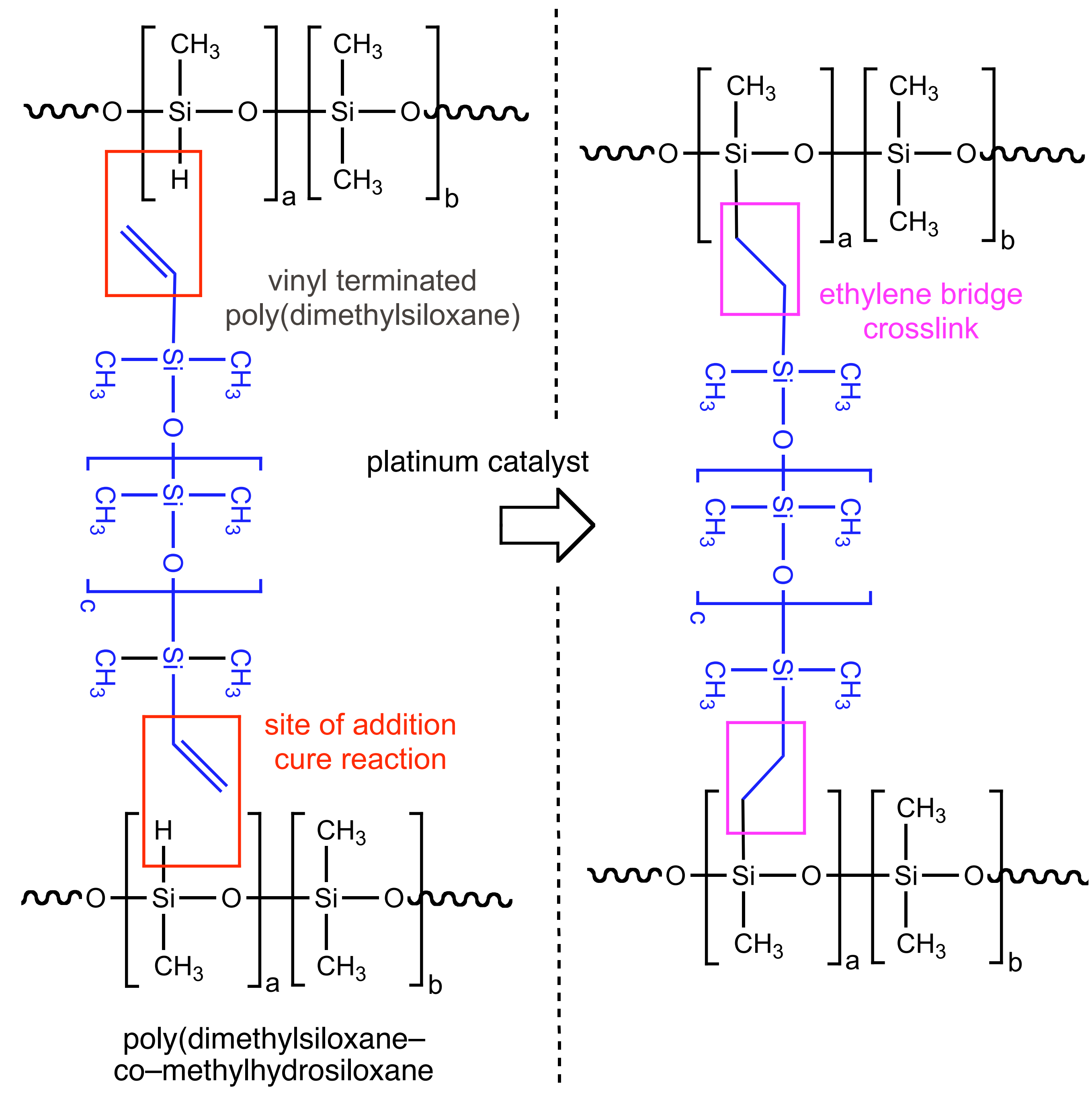

Figure 2. Simplified representation of the curing chemistry for addition-cure, platinum-catalysed silicone elastomers.

LNG was recoverable, irrespective of the cure time and cure temp. (Figs. 3C \& 3D, black squares). Partial recovery was possible with non-micronised LNG (white squares); however \% LNG recovery significantly decreased with increasing cure time (Fig, 3D) and cure temp (Fig. 3C). We concluded that LNG was reacting with the SE system, to an extent determined by its solubility in the $S E$ (hence the temperature, time and particle size dependency). Both the ethinyl and enone functional groups in LNG (Fig. 1) have potential to undergo hydrosilylation reactions, similar to the SE cure reaction (Fig. 2). To test this hypothesis, the DAP+LNG matrix rings were manufactured using Nusil DDU-4320 SE with a lower cure temp. This time, rings containing micronised LNG offered partial recovery of $L N G$, albeit only at lower cure temps.
(Fig. 3A, black squares) and shorter cure times (Fig. 3B). The nonmicronised LNG typically gave $80 \%$ recovery at most cure times and temps (Figs. 3A \& 3B, white squares), although recoveries decreased at extreme cure conditions. Neither dispersion of the LNG component in a silicone oil prior to addition to the SE (data not shown) nor initial addition of LNG to only one part of the SE were useful in increasing LNG recovery (Fig. 4).



Cure Time (min) @ $160{ }^{\circ} \mathrm{C}$

Figure 3. Percentage recovery of $L N G$ from addition-cure silicone elastomer vaginal rings as a function of SE type, cure time and cure temperature. Mean values $(n=4)+1-S D$.

LNG materials with different particle size characteristics (e.g. nonmicronised vs. micronised) had a very significant impact on \% LNG recovery from DDU-4320 (Fig. 5A). The best $L N G$ recovery values

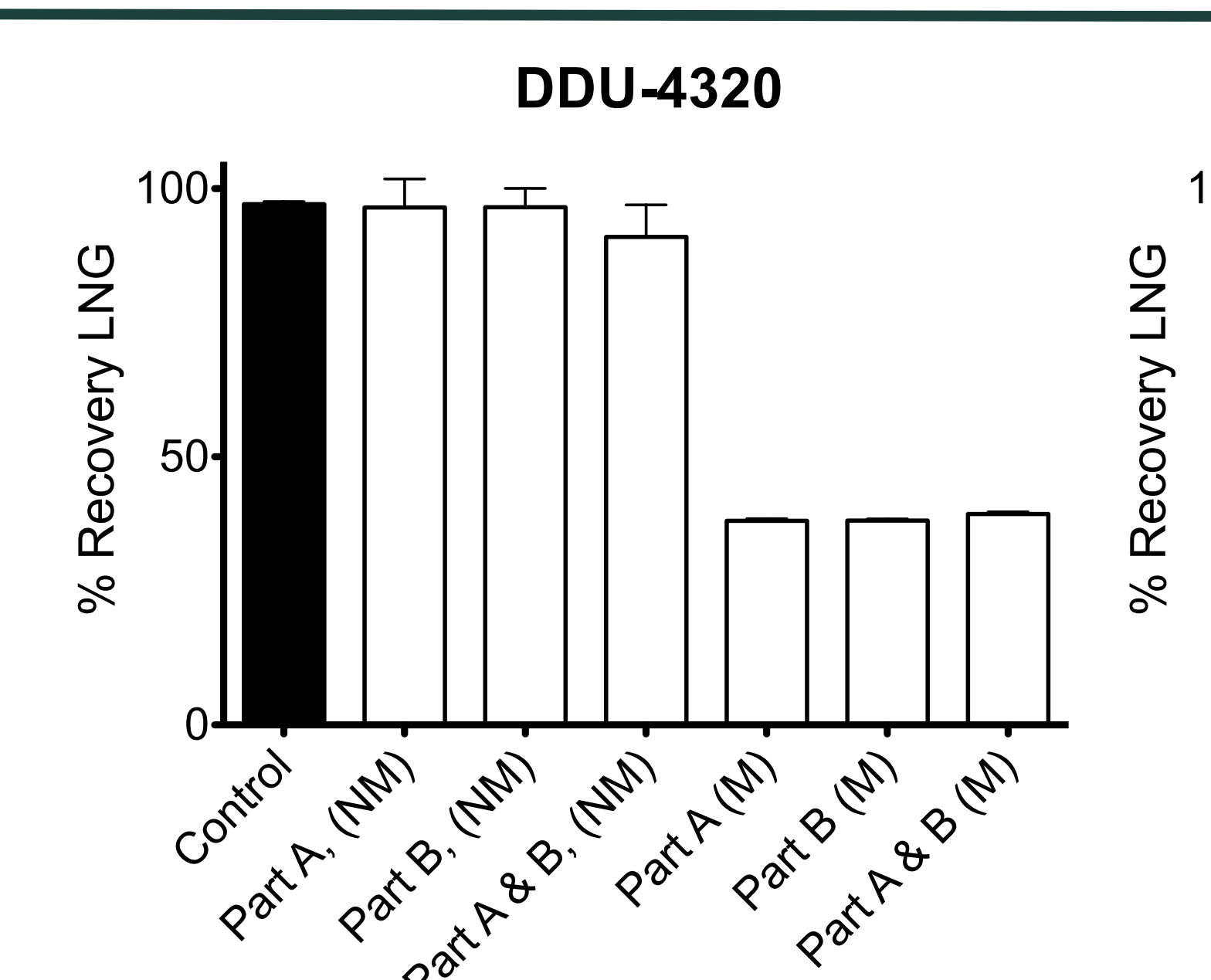

Figure 4. Effect of addition of LNG to different parts of the SE system

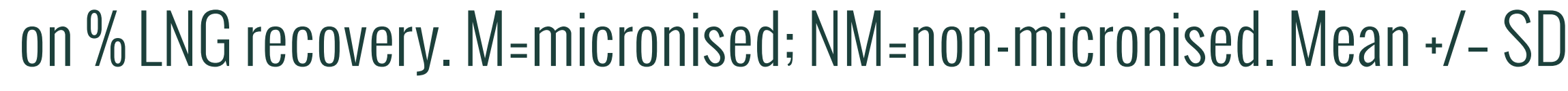
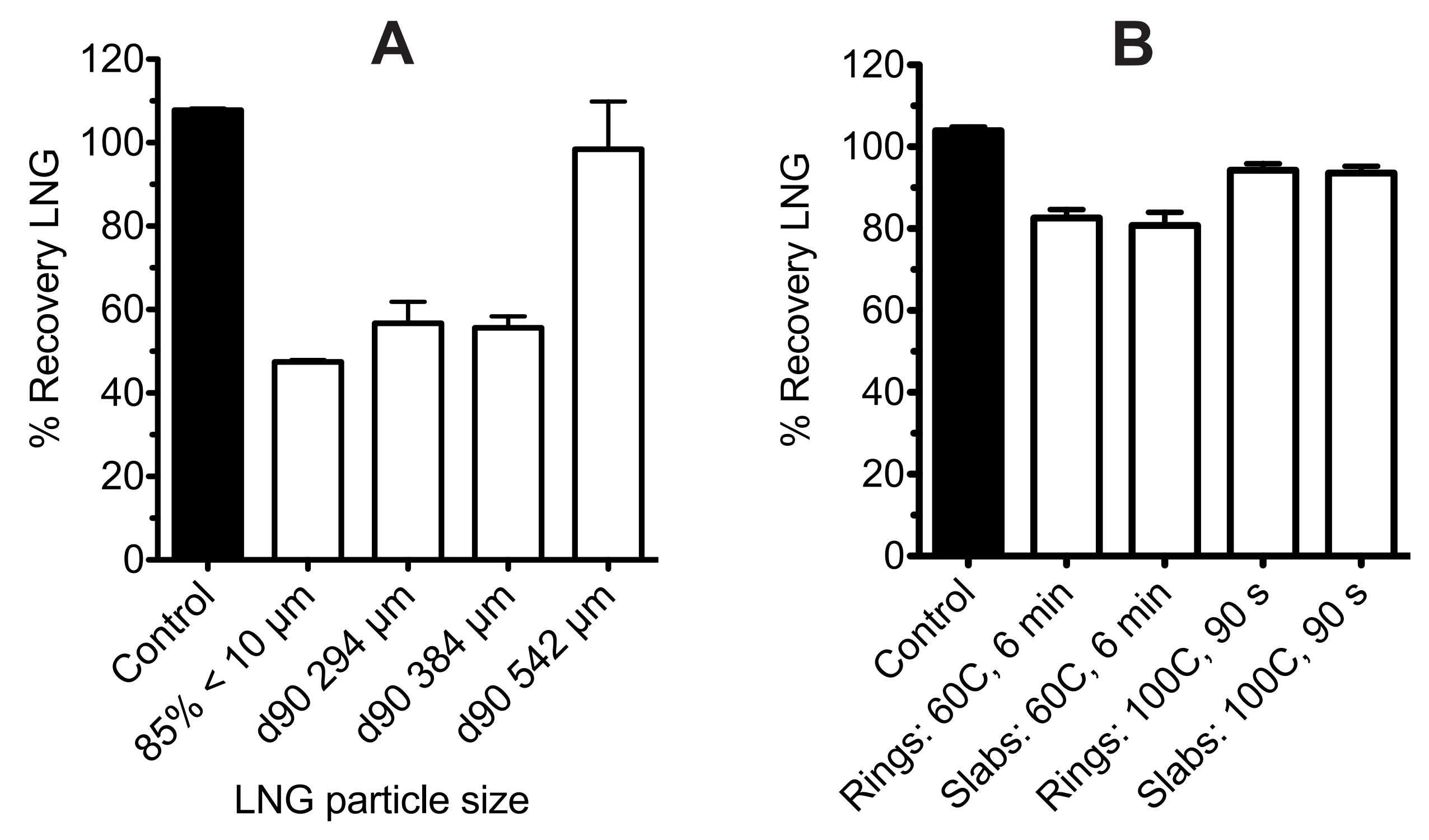

Figure 5. Influence of LNG particle size distribution (A) and cure time and temp. (B) on LNG recovery in DDU-4320 rings and slabs. For A, cure time $=90$ s, cure temp. $=100^{\circ} \mathrm{C}$. For B, non-micronised LNG was used.

$(>90 \%)$ were achieved with large particle size (non-micronised) LNG, low SE cure temperatures and short SE cure times. The data demonstrate that by carefully controlling (i) LNG particle size, (ii) SE cure temperature, and (iii) SE cure time, it is possible to lower LNG solubility in the SE during ring manufacture, and thereby minimise covalent bonding of LNG to the SE. With raw material controls, process controls, and reproducible assay values of greater than $90 \%$, this formulation is now ready to proceed to Phase 1 clinical testing. 